writings in recent years. The excellence of the clinical descriptions and the clear, easily read prose amply compensate for a few minor blemishes, such as a tendency to overstatement and an unhappy addiction to the word 'unfortunately'. In the report of his survey, the author makes use of the system of classification devised by Balf and Ingram in 1955, which has much to commend it although it has not received wide acceptance. Terms such as 'rigid-spastic tetraplegia' aro not in present-day use by most people working with spastic children and, intelligible though they may be to the initiated, they will scarcely commend the book to the unspecialized reader seeking to acquire a working knowledge of cerebral palsy. Nevertheless, this volume is an important addition to the library of the specialist and the worker in daily contact with spastic children, its chief merits being the valuable historical reviews, the analysis of the antecedents of cerebral palsy and the wealth of descriptive detail, which bears testimony to the author's extensive practical experience.

R. G. Mrtcheli.

\section{Paramedical Microbiology}

By Prof. Stanley E. Wedberg. Pp. xv +462 . (Now York: Reinhold Publishing Corporation; London: Chapman and Hall, Ltd., 1963.) 54s.

T HIS book is intended for those studying pre-clinical nursing, medical technology and allied subjects. In consequence, it is, in the main, an introduction to medical microbiology, but, while this may be true of the theory, it is by no means always true of the practical aspects, which are often given in considerable detail. The contents of the book cover the following main topics: the structure and metabolism of bacteria; their cultivation; disinfection and sterilization; the microbiology of water, sewage, soil, air and food; and descriptions of the main pathogenic bacteria and viruses. Chemotherapy, epidemiology and immunity are treated more briefly. The fungi receive a little attention. The list of about forty references is well chosen on the whole, in view of the intended audience of the book, but it could profitably have been increased to at least twice the length.

Of these chapters, those on disinfection and sterilization are the best. All the practical sections are sound, cloar and detailed. Some sections are not very up to date (bacteriophages, for example), and a number of topics of present-day interest and increasing importance receive little or no attention (for example, bacterial geneties). There is a good deal of moralizing, though this is not necessarily a bad thing in a text intended to impress on students the importance of the subject in terms of human suffering. It is written in a clear, readable style with a pawky sense of humour, which may call forth varied reactions. The author has evidently taken a good deal of trouble to explain the reasons for many of the procedures described.

The book is excellently produced and reasonable in price. The illustrations are of a high standard, clear and well chosen. It can be recommended as an introductory text in medical microbiology. P. H. A. SNeAtr

\section{The Story of Edinburgh Zoo}

The Royal Zoological Society of Scotland and the Scottish National Zoological Park. An account of their Origin and Progress. By $\mathrm{T}$. H. Gillespie. Pp. xii +123 . (Slains, Aberdeenshire: Michael Slains Publishers, Limited, 1964.) $30 s$.

THE Zoological Society of Scotland was founded in

1909; the Zoological Garden on Corstorphine Hill, Edinburgh, was opened on July 15, 1913, and the Society became the Royal Zoological Society of Scotland in 1947. Mr. T. H. Gillespie was a leading spirit in this venture and was the Society's secretary and director of the Park until his retirement in 1950.
As Mr. Gillespie states in the preface, it is desirable that the history of the Society and of the Park should be placed on record and with this everyone would agree, but even though these events must be of an especial interest to those concerned with the Society, and no doubt to the citizens of Edinburgh, it is questionable whether they have such appeal to wider circles as to warrant the publication of a book. This material might be thought more appropriate to the archives and a chapter in the zoo guide. People interested enough to read about the zoo might also be expected to want to read about the animals kept there and much more might have been said about them. It is true that the author has already written on the king penguins (A Book of King Penguins, 1932), but among many other animals, several species of antarctic penguin have been kept in the gardens in considerable numbers over the years and many have been bred there, thus providing a valuable opportunity for their study.

Photographs and drawings are included, and there is an appendix describing the Royal Edinburgh Zoological Gardens which existed from 1839 until 1957.

$$
\text { J. Yealland }
$$

Virus Diseases of Apples and Pears

Edited by Dr. A. F. Posnette. (Technical Communication No. 30 of the Commonwealth Bureau of Horticulture and Plantation Crops, East Malling.) Pp. xi+141. (Farnham Royal: Commonwealth Agricultural Bureaux, 1963.) 35s.; 5.25 dollars.

GYMPTOMATOLOGY occupies a peculiarly important $\$$ place in plant virology. Often, characteristic symptoms provide the only means of recognizing a virus disease; equally, the ability of viruses to cause characteristic symptoms in particular host plants is, presumably, a genetic property of the viruses and thus reflects fundamental differences of a kind which will always have their place in any scheme of classification of plant viruses. Novertheless, symptoms are merely the visible manifestation of a virus disease and result from an interaction between pathogen and plant.

It is common experience to find that a particular species displays apparently similar symptoms when infected with distinct viruses, and that one and the same virus may cause quite distinct symptoms in different varieties of the same species. Thus, symptoms do not, of themselves, characterize a virus, but the error of using the term 'virus' when virus disease is meant is still a common one and is not avoided by many of the contributors to this volume. In fact, as the editor himself says in his introduction, little or nothing is known of the viruses which cause diseases in apple and pear and it is not at all unlikely that diseases now considered distinct may have similar or related causes. But this is the only substantial criticism of an otherwise excellent handbook which shows every evidence of the care which must have gone into its production.

Virus Diseases of Apples and Pears provides, at a modest price-considering the quality of the coloured plates and photographs-a conspectus of the various virus diseases of apple and pear so far described, contains much hitherto unpublished information and is furnished with a useful bibliography. This handbook should be of value both to those who work with these crops in the field and to those who wish to gain an acquaintance with progress in this specialized branch of fruit-tree pathology. It has the merit of having been compiled by specialists under the general editorship of Dr. A. F. Posnette, and, wisely, has been issued in loose-leaf form to allow for future additions and amendments without the attendant cost of re-editing and reprinting the entiro volume. Considering that, twenty years ago, the existence of virus diseases in pome fruits was scarcely recognized, this handbook is a remarkable record of progress in their recognition and control.
C. H. Cadman 